\title{
Malcolm X and the Philosophical Theology of James $\mathrm{H}$. Cone
}

\section{Maurice Pugh ${ }^{1,2}$}

Published online: 20 July 2020

(C) The Author(s) 2020

\begin{abstract}
Malcolm X emerged as one of the foremost and formidable leaders of the late 50s and early $60 \mathrm{~s}$. He esteemed and affirmed black culture, history, and beauty, thus igniting a nationalistic movement that injected "Black Power" and "Black Pride" into the America lexicon. Malcolm's pro-black message also shaped the philosophy and methodology of a young theologian named James H. Cone who was struggling at the time to construct a Christian faith relevant to an oppressed and frustrated Black community. Cone blazed a new trail in the 1960s as the prophetic voice and the prolific scholar who creatively integrated the social justice theology of Dr. Martin Luther King, Jr., with the black ideology of Malcolm X.
\end{abstract}

Keywords James Cone $\cdot$ Malcolm X · Black theology $\cdot$ Black power movement · Black nationalism

America encountered irrefutable social turmoil and racial discord during the 1960s. Consequently, an exasperated Black America, no longer willing to accept systemic injustice, rejected segregation and discrimination, unprosecuted racial violence, and second-class citizenship as status quo. Dr. Martin Luther King, Jr., advocated peaceful marches and nonviolent sit-ins to accomplish social integration and racial equality. However, Malcolm X argued that oppressors will never willingly grant equality; it must be demanded and taken "by any means necessary." In the midst of this turbulent period, a relatively unknown theologian named James Cone emerged from a rural town in Arkansas to confront the abstract and irrelevant definitions of white mainstream theology and to speak to the social conditions of Black America (Hopkins 2002, 15). Arguably, King and Malcolm represented the two most recognizable and preeminent leaders of the $60 \mathrm{~s}$. At the same time, James Cone is considered the most prolific and

Maurice Pugh

mauricepugh15@gmail.com

1 New Life Fellowship, Arlington, TX, USA

2 Dallas Theological Seminary, Dallas, TX, USA 
seminal Black theologian of that era. Together, the three established the cultural, theological, and ideological foundation for African Americans at the end of the twentieth century and their impact continues ad infinitum.

James Cone has written that "a colorless Christianity is a joke - only found in the imaginary world of white theologians" (Cone 1999c, xx). He argues that a socially relevant theology must identify with the racial, cultural, and historical heritage of an oppressed community. "There is no place in black theology for a colorless God in a society where human beings suffer precisely because of their color" (Cone 1990, 84). Thus, "blackness whetted my appetite for learning how to do theology with a black signature on it and thereby make it accountable to poor black people" (Cone 1999c, xxii). The Black Nationalism of Malcolm X, which gave rise to the Black Power movement, contributed significantly to Cone's theology. Cone explains: "to understand white racism and black rage in America, I turned to Malcolm X and Black Power. Malcolm X did not enter my theological consciousness until I left seminary and was challenged by the rise of the black consciousness movement in the mid 1960s. Black Power, a child of Malcolm, forced me to take a critical look at Martin King and to discover his limits" (Cone 1996, 191). Cone's search for a theology deriving from, and affirming the black experience, compelled him to incorporate Malcolm X's black nationalism into his black theology.

\section{Cone and Black Identity}

James Cone arrived at Adrian College in 1966, a small, isolated community in Michigan. With few distractions, Cone was afforded the opportunity to reflect and "make sense of the gospel and the black struggle for justice" (Cone 1986, 42). While Cone was formulating his theological system focusing on black suffering, two monumental events occurred that contributed to black theology's development. First was the birth of the Black Power movement. During a Civil Rights march on June 16, 1966, in Greenwood, Mississippi, Stokely Carmichael, the chair of the Student Non-violent Coordinating Committee was arrested, and upon his release gave a now-famous statement using the term "Black Power," to which the crowd responded passionately. Carmichael's Black Power sparked something within young radicals who, for some time, had adhered to King's philosophy of nonviolence. Instead of "freedom now," "black power" became the catch-phrase, with "we shall overrun" substituted for "we shall overcome."

The Christian response to the Black Power movement created the second monumental event in the development of Cone's black theology. An ad hoc group of clergymen formed the National Committee of Negro Churchmen. In July 1966, Dr. Benjamin A. Payton, the executive of the Commission on Religion and Race of the National Council of Churches, called a meeting to discuss the rise of Black Power and the rejection by white ministers. They believed that King had not responded satisfactorily to the Black Power movement and that therefore it was time to mobilize the radical Black ministers in the North for leadership in the next stage of the struggle. The pastors believed that a resolution had to be provided to address the Christian response to the Black Power movement. Therefore, they agreed to publish a statement to clarify their position and address the theological implications of the Black Power movement. On July 31, 1966, the ad hoc group published a full-page advertisement in The New York Times. Its stated purposes were twofold: (1) to articulate a 
concern "about the crisis brought upon our country by historic distortions of important human realities in the controversy about Black Power," and (2) to clearly and carefully place in context the realities and to examine current distortions. Both the Carmichael incident, with all of its rhetorical and political significance, and this published statement, which so impacted the public discourse, helped Cone's black theology come to fruition (Cone 1986).

Cone's enduring discontent with theology's inability to address the social inequities experienced by Black people compelled him to undergo a sustained search. He was intent on linking Christianity with the black struggle for freedom. As Cone has stated, "theology seemed irrelevant to black life and suffering. So, I quit reading it and devoted myself to reading secular writers, mainly blacks, who at least did not use religion to cover up human suffering" (Cone 1986, 43). Concurrently, the 1967 Detroit uprisings intensified Cone's conviction that he must address the plight of Black Americans. Seventy miles from Adrian College, the Detroit insurrections resonated closer to Cone. He remembered: "forty-three people were killed in the Detroit riot. Similar events occurred that summer in many other American cities. I had to say something now about God and black people's struggle for freedom" (Cone 1986).

Moreover, Cone increasingly recognized that white theologians rejected the relationship between Christianity and Black Power, which also troubled him. As he recalls, "the challenge to say something about God and the black liberation struggle was enhanced as I read and heard the comments of white theologians and preachers who condemned black violence but said nothing about the structural white violence that created it" (Cone 1986, 44). He continues: "After spending six years of studying white theology in graduate school, I knew that the time had come for me to make a decisive break with my theological mentors" (Cone [1969] 1997a, xi) but not without creating internal tension. He explains: "I did not know much about my own theological tradition which had given rise to my rebellion. I was struggling to become a black radical theologian without much knowledge of the historical development of AfricanAmerican religion and radicalism. I had studied a little 'Negro History' in high school and college, but no text by a black author had been included in my theological curriculum in graduate school. That was one of the things that made me so angry" (Cone [1969] 1997a).

Accordingly, the Black Power movement, the National Conference of Black Churchmen's published document on Christianity and Black Power, black riots and social unrest, and Christianity's irrelevancy to black suffering converged in Cone's theological consciousness, creating an irrepressible conviction that he must create a theology from the experience of Black people. He describes the internal liberation he felt when he yielded to this new method of doing theology:

The turn to blackness was an even deeper metanoa-experience than the turn to Jesus. It was spiritual, radically transforming my way of seeing the world and theology. Before I was born again into thinking black, I thought of theology as something remote from my history and culture, something that was primarily defined by Europeans whom I, at best, could only imitate. Blackness gave me new theological spectacles, which enables me to move beyond the limits of white theology and empowered my mind to think wild, heretical thoughts when evaluated by white academic values. Blackness opened my eyes to see AfricanAmerican history and culture as one of the most insightful sources for knowing 
about God since the Bible was declared a canon. Blackness whetted my appetite for learning how to do theology with a black signature on it and thereby make it accountable to poor black people and not to the privileged white theological establishment (Cone 1999b, 251).

Hence, Cone's encounter with Black Power transformed his theological approach, bridging his Christian faith with black suffering. His newly discovered theological method provided the language to speak to "those being economically exploited and politically marginalized because of their skin color" (Cone 1984, 5).

By the summer of 1968, Cone was no longer able to contain his rage. Angry with the white churches for their discontent, complacency, and theological advancement of racism, in addition to their rejection of the Black Power philosophy, he thus decided to write a brief manifesto identifying Black Power with the gospel of Jesus. "I knew that the persuasive presentation of that thesis would cause the theological hairs to stand straight up. The writing of this essay provided the occasion for me to declare my liberation from the bondage of white theology" (Cone 1986, 45). Hence, "Christianity and Black Power" inaugurated Cone's journey to create a theology from the black experience. It officially established his radical break from white Christianity and revealed the passion that burned within him to integrate his Christian faith with his black identity. "Writing fifteen hours per day for one month, Cone set out to show that "Black Power is not the antithesis of Christianity. It is, rather, Christ's central message to twentieth-century America" (Cone [1969] 1997a, 1). Of his first book, He says:

Black Theology and Black Power (1969) was my first public theological cry. It was like a baby coming to voice at birth, screaming in response to hurt. I will never forget what I felt back then-the excitement and self-confidence one feels when seized by the Spirit that refuses to let go until the truth is spoken bluntly and without compromise. I thought of the prophet Jeremiah because the experience felt like 'a burning fire shut up in my bones' (20:9), an experience so unforgettable that I can retell it at a moment's notice and feel the energy surge again (Cone 2004, 204).

Black Theology and Black Power provided a systematic response to Black Christians who were trying to reconcile whether it was possible to affirm their black identity and their Christian faith, and whether the gospel of Jesus denied Black Power or was consistent with it. Cone had to consider the legitimate concerns of the Black Power movement, but from a Christian perspective. Hence, Malcolm X as the leading proponent of black nationalism, provided Cone a model and method for his social commentary and theological treatise that shaped his religious framework to create a theology suited to the unique concerns of Black America.

\section{Black Nationalism: Cone's Ideology in Context}

Black Power and black consciousness converged to create the context for Cone's ideology, creating an orientation toward blackness and a link to black suffering. Although King's theology sufficiently connected Christianity to justice, Cone found 
that King "was silent about the meaning of blackness in a world of white supremacy" (Cone 1999c, 2). Cone argued, "it is one thing to recognize that the gospel of Jesus demands justice in race relations and quite another to recognize that it demands that African Americans accept their blackness and reject its white distortions. When I turned to Malcolm, I discovered my blackness and realized that I could never be who I was called to be until I embraced my African heritage - completely and enthusiastically" (Cone 1999c).

Malcolm X was the most vocal and recognizable proponent of black nationalism and black militancy during the late 1950s and early 1960s. As a nationalist, he raised black people's consciousness on the value of black culture, history, and race. Simultaneously, his militancy spoke fiercely against the hypocrisy of the white establishment. ${ }^{1}$ Michael Eric Dyson has said, "Malcolm spoke out loud what many blacks secretly felt about racist white people and practices, but were afraid to acknowledge publicly" (Dyson 1995, 10). Malcolm articulated a nationalistic philosophy with a militant conviction, passion, and intelligence unlike what Blacks had previously heard.

Malcolm's black nationalism and militant influence laid the foundation for an emerging group of young radicals who followed King but was impatient with King's nonviolent method. As Cone notes, "strictly speaking, black power appeared in the spring of 1966, when Stokely Carmichael verbalized the unwillingness of black people to live under white definitions of their humanity" (Cone 1970b, 1085). William Sales further explicates: "Black Power became the orientation of the latter half of the " $60 \mathrm{~s}$ decade because Malcolm X struggled uncompromisingly to restore the African American nationalist tradition. Without Malcolm's ideological intervention the slogan 'Black Power' would not have emerged as quickly nor would it have been so rapidly taken up by so many" (Sales 1994, 170). Therefore, Malcolm's notion of Black Power

\footnotetext{
${ }^{1}$ Malcolm X's scholars agree that he must be understood from the perspective of the personal and philosophical metamorphosis that occurred during his life. Many describe the "stages" of Malcolm's intellectual development. George Breitman, for example said: “The reader who is trying to understand Malcolm's development would therefore do well, when he comes across any passage - in the Autobiography, in Malcolm $X$ Speaks, or anywhere else - always to ask himself: 'Is this from Malcolm's Black Muslim period, is it from the transition period, or is it from the final period?"' (Breitman 1967, 23-24). Sales argued: "We can identify three periods in the development of the political thought of Malcolm X. The first period, from 1952 through most of 1962, was characterized by the theology of the Nation of Islam. Black nationalism's renewed popularity owed much to the Nation of Islam, which offered a scathing critique of White America. The second period in his thinking reached its highest development with the creation of the Muslim Mosque, Inc. and the speeches of the spring of 1964. With his trip to the Middle East and Africa in late April and early May 1964, Malcolm X ushered in the final period in the development of his thinking, the period of PanAfrican internationalism" (Sales 1994, 60-61). Arguably, at least two critical periods in Malcolm's life defined the progression of his intellectual development: his conversion to the Nation of Islam in 1948 and his split from them in March 8, 1964. To define Malcolm by these two periods does not seek to oversimplify his life. Dyson correctly suggests, "Malcolm was a complex figure, that his thought evolved, and that his moral vision was transformed over the course of his complicated, heroic life" (Dyson 1995, xxii). Cone argued: "After his break with the Nation of Islam, which he announced on 8 March 1964, a new Malcolm began to emergeindependent and free of the narrow straitjacket of the religious philosophy of Elijah Muhammad. His views about America and the black struggle changed. Moreover, he moved toward Martin and closer to the mainstream of the civil rights movement" (Cone 1991, 183). Three noticeable changes occurred in Malcolm's life after his split from the Nation of Islam and his trips to Mecca and Africa: (1) Malcolm moved toward cooperation with other black leaders, including Martin Luther King; (2) He was flexible, willing to work with different social and political groups in order to accomplish the goal of justice; (3) Malcolm changed his terminology from separation to independence. His emphasis was focused not on separating from whites, but establishing independence for black people.
} 
confronted Cone with the undeniable reality that Christianity must incorporate the black experience and separate from white religion to address black suffering. The link between Black Power and Christianity led Cone to examine Malcolm's Black Nationalism.

Malcolm's black nationalism elevated black consciousness to a new level because he passionately spoke to (and on behalf of) Black people. ${ }^{2}$ Cone describes Malcolm's significance to black life in this way:

No one had a greater impact on the cultural consciousness of African-Americans during the second half of the 20th century than Malcolm X. More than anyone else he revolutionized the black mind, transforming docile Negroes and selfeffacing colored people into proud blacks and self-confident African-Americans. Civil rights activists became Black Power militants and declared, 'It's nation time.' Preachers and religious scholars created a black theology and proclaimed God as liberator and Jesus Christ as black. College and university students demanded and won black studies. Poets, playwrights, musicians, painters and other artists created a new black aesthetics and ardently proclaimed that 'black is beautiful' (Cone 1992, 1150).

Black people's dehumanized and impoverished conditions angered Malcolm. Arguably, no one characterized black rage as vividly and forcefully as Malcolm X. Cornel West has declared that

Malcolm X articulated black rage in a manner unprecedented in American history. His style of communicating this rage bespoke a boiling urgency and an audacious sincerity. The substance of what he said highlighted the chronic refusal of most Americans to acknowledge the sheer absurdity that confronts human beings of African descent in this country - the incessant assaults on black intelligence, beauty, character, and possibility. His profound commitment to affirm black humanity at any cost and his tremendous courage to accent the hypocrisy of American society made Malcolm X the prophet of black rage-then and now (West 1993, 136).

Malcolm incessantly articulated his discontent with black suffering. He said: "I'm one of the 22 million black people who are the victims of Americanism. One of the 22 million black people who are the victims of democracy, nothing but disguised hypocrisy, and I see America through the eyes of the victim. I don't see any American dream; I see an American nightmare" (Malcolm X 1965a, 26).

\footnotetext{
${ }^{2}$ Again, Malcolm studies require the critical understanding that his life underwent several transformations. Dyson summarized accurately: "Malcolm lived only fifty weeks after his break with the Nation of Islam, initiating his last and perhaps most meaningful transformation of all: from revolutionary black nationalist to human rights advocate. Although Malcolm never gave up on black unity or self-determination-and neither did he surrender his acerbic wit on behalf of the voiceless millions of poor blacks who could never speak their pain before the world - he did expand his field of vision to include poor, dispossessed people of color from around the world, people whose plight resulted from class inequality and economic oppression as much as from racial domination" (Dyson 1995, 14).
} 
Consequently, Malcolm rejected nonviolence and integration as a viable answer to systemic racism: "When I say fight for independence right here, I don't mean any nonviolent fight, or turn-the-other-cheek fight. Those days are gone" (Malcolm X 1965b, 49). Malcolm urged his black audience to "look right now what's going on in and around Saigon and Hanoi and in the Congo and elsewhere. They are violent when their interests are at stake. They're violent in Korea, they're violent in Germany, they're violent in the South Pacific, [and] they're violent wherever they go. But when it comes time for you and me to protect ourselves against lynchings, they tell us to be nonviolent" (Gallen 1992, 101).

Instead, he promoted self-defense over nonviolence, arguing that Black people had a right to protect themselves. On March 20, 1964, an interviewer named Joe Rainey asked Malcolm if he intended to emphasize self-defense or "people buying guns and shooting up places."3 Malcolm responded succinctly:

in areas where the government is either unable or unwilling, then it's time for the so-called Negro to be a man as others are men and defend himself .... We're not telling anybody to break the law, but we're telling the so-called Negroes to read the Constitution, and in the context of his constitutional rights he should do whatever is necessary to defend himself, especially since the government itself has proven its inability or else unwillingness to come to the rescue and defend our people when they are being unjustly attacked (Gallen 1992, 156). ${ }^{4}$

Malcolm advocated both self-defense and militant protest against the structures of racism and segregation. In what became a famous quote, he announced: "we declare our right on this earth to be a human being, to be respected as a human being, to be given the rights of a human being in this society, on this earth, in this day, which we intend to bring into existence by any means necessary."

Moreover, Malcolm rejected integration as the goal for Black Americans, arguing that "God wants us to separate ourselves from this wicked white race here in America because this American House of Bondage is number one on God's list for divine destruction today" (Karim 1971, 72). Integration would do more to harm the Black community than help it. Integration would further challenge Black Americans to accept white values rather than appreciate black culture. He also argued that

the only way the black people caught up in this society can be saved is not to integrate into this corrupt society, but to separate from it, to a land of our own,

\footnotetext{
${ }^{3}$ Sales (1994) described the misunderstanding about Malcolm's view on violence: "The question of violence was at the center of Malcolm X's conception of the international implications of the Black man's freedom struggle (the struggle against racism and for civil and human rights). Malcolm X generated more controversy around his stance on violence than his analysis of the nature of White people. Malcolm X's position on the role of violence in social change often confused his adherents and his detractors. He was always careful to preface his statements about the organization of rifle clubs by Black people with the expression 'in those areas where the government cannot or will not protect' its Black citizens" (p. 77).

${ }^{4}$ Malcolm told Kenneth B. Clark in an interview: "Any Negro who teaches other Negroes to turn the other cheek is disarming that Negro. Any Negro who teaches Negroes to turn the other cheek in the face of attack is disarming that Negro of his God-given right, of his moral right, of his natural right, of his intelligent right to defend himself. Everything in nature can defend itself, and is right in defending itself, except the American Negro" (Gallen 1992, 139).
} 
where we can reform ourselves, lift up our moral standards, and try to be godly. Every time I mentioned 'separation,' some of them would cry that we Muslims were standing for the same thing that white racists and demagogues stood for. I would explain the difference. 'No! we reject segregation even more militantly than say you do! We want separation, which is not the same! The Honorable Elijah Muhammad teaches us that segregation is when your life and liberty are controlled, regulated, by someone else. To segregate means to control. Segregation is that which is forced upon inferiors by superiors. But separation is that which is done voluntarily, by two equals - for the good of both! (Malcolm X 1973, 282-83).

Malcolm rejected integration because he believed it forced Black people to accept White Americans' values and culture. He scoffed at the supposed link between integration and freedom. Malcolm believed that Black people needed to reject the notion that freedom could be defined by integration with and acceptance from Whites. He maintained: "If whites can be human without being integrated with blacks, then blacks can be human without associating with whites" (Cone 1991, 109).

Instead of seeking acceptance from the White community, Malcolm advised Black people to appreciate and love their own heritage, history, and culture. He criticized White Americans for the psychological damage of self-hatred inflicted upon Black people during four-hundred years of slavery and racial segregation. He said: "[The white man] kidnapped us four hundred years ago, brought us here and stripped us of our history, stripped us of our culture, stripped us of our language, stripped us of everything that you could use today to prove that you were ever part of the human family, brought you down to the level of an animal, sold you from plantation to plantation like a sack of wheat, sold you like a sack of potatoes, sold you like a horse and a cow, and then hung you up from one end of the country to the other." (Malcolm X 1965b, 80).

To Malcolm, the cultivation of self-hatred was the worst crime White people had committed against Blacks. He argued that Blacks hated their culture because they had been trained to evaluate it against white culture. Who are they to be compared to, Malcolm argued. In addition, Malcolm suggested that White Americans had created a culture deeply embedded with a negative and self-hatred stigma about blackness. In this schema, everything associated with black was understood to be evil, while everything associated with white was assumed to be pure and righteous. ${ }^{5}$

Malcolm believed the time had come for African Americans to cease hating themselves and their blackness, calling upon them instead to recognize their

\footnotetext{
${ }^{5}$ Malcolm told a Detroit audience: "We hated our heads, we hated the shape of our nose, we wanted one of those dog-like noses, you know; we hated the color of our skin, hated the blood of Africa that was in our veins. And in hating our features and our skin and our blood, why we had to end up hating ourselves. Our color became to us a chain - we felt that it was holding us back; our color became to us like a prison which we felt was keeping us confined, not letting us go this way or that way. We felt that all of these restrictions were based solely upon our color, and the psychological reaction to that would have to be that as long as we felt imprisoned or chained or trapped by black skin, black features, and black blood, that skin and those features and that blood holding us back automatically had to become hateful to us. It made us feel inferior; it made us feel inadequate; it made us helpless; and when we fell victims of this feeling of inadequacy or inferiority or helplessness, we turned to somebody to show us the way" (Breitman 1967, 169).
} 
beauty, culture, and history. He began to reverse the psychological damage and cultural hatred inflicted upon Black people by emphasizing the inherent dignity and beauty associated with black culture. As West has noted, "Malcolm X's notion of psychic conversion holds that black people must no longer view themselves through white lenses. He claims that black people will never value themselves as long as they subscribe to a standard of valuation that devalues them" (West 1993, 137). Malcolm asked Black people to view themselves as Black people first, urging that they look at life through the lens of black existence. As he said, "I'm black first. My sympathies are black, my allegiance is black, my whole objectives are black. I am not interested in being American, because America has never been interested in me" (Goldman 1979, 6).

Moreover, Malcolm believed that Black people had to consciously dismiss their internalized self-loathing and learn to love themselves.

Malcolm did more than any person of his day to instill in African Americans a sense of self-worth or 'somebodyness.' He believed this to be the most important key to black liberation. He rejected the negative images of blackness portrayed by white Christianity and claimed that Islam stood for everything positive for blacks, while Christianity proclaimed the opposite. More than any other leader he stressed the importance of black culture and black consciousness. Malcolm taught blacks to love and respect themselves (Burrow 1994, 16).

Therefore, Malcolm challenged Black people to love themselves first, insisting that they could not love others until they first loved themselves. He expressed this concern when interviewed by Kenneth Clark in 1963, "Mr. Muhammad teaches us to love each other, and when I say love each other, [I mean] love our own kind. This is all black people need to be taught in this country" (Gallen 1992, 82). Magnus Bassey has written that "Malcolm X was able to help restore heritage, place, the pride of race and the pride of self and history which had eroded African Americans during the four hundred years of enslavement" (Bassey 1999, 50).

Additionally, Malcolm's black nationalism rejected and rebuked Euro- American Christianity, or, as he called it, "white Christianity." Malcolm was suspicious and skeptical of Christianity promulgated by Whites. Cone writes: "Malcolm began his ministry with a scathing attack upon the white man's Christianity and the role it played in the physical, mental, and spiritual oppression of black people" (Cone 1991, 166). ${ }^{6}$ Additionally, he argues that "Malcolm X was the most formidable race critic in the United States during the twentieth century. He was the great master of suspicion in regard to American democracy and the Christian faith" (Cone 1999b, 256). Malcolm maintained that Euro-American Christianity was hypocritical, brainwashing African Americans and leaving them mentally and spiritually dead. Dwight Hopkins interprets this rhetoric:

\footnotetext{
${ }^{6}$ Cone (1991) continues, "According to Malcolm, whites had no moral conscience that was applicable to their relations with blacks. The morality which whites derived from Christianity was limited to their own kind and never applied to blacks and other Third World people, because whites did not regard them as human beings. Slavery, colonization, and segregation - which were accompanied by the 'destruction of the African civilization"- clearly demonstrated the devil-like behavior of whites in Europe and America toward the dark-skinned peoples of the world."
} 
Malcolm spoke the truth about white theology and white Christianity. He indicted white Christians for brainwashing black Americans into believing in white Jesus. Malcolm surmised that all the dirty-looking, scrawny-built, stringy-haired white male pictures of Jesus found in thousands of black homes and churches throughout the United States were only the reflections of white male models who had posed for European artists during the European Renaissance and Middle Ages. A white portrait of Jesus had nothing to do with God. On the contrary, a white divinity served further to enslave black folks with psychological and selfdenigrating chains (Hopkins 1993, 172).

As Malcolm himself explained it, "this same American white man kept the truth hidden from our people. He made us spiritually blind by depriving us of the light of truth. During the four hundred years that we have spent confined to the darkness of ignorance here in the land of bondage, our American enslavers have given us an overdose of their own white-controlled Christian religion" (Malcolm X 1965b, 71).

From Malcolm's vantage point, White Christians were not sympathetic of black oppression; neither did they seek to alleviate it. Instead, Christianity identified with white values and affirmed all things associated or commensurate with those values. Malcolm did not see where Christians separated their faith from their whiteness; the two were inextricably linked. He said: "The white man never has separated Christianity from white, nor has he separated the white man from Christianity. When you hear the white man bragging, 'I'm a Christian,' he's bragging about being white" (Malcolm X 1962, 1965a, b, 24). Furthermore, Malcolm attacked Whites for using Christianity to justify the enslavement of Black people. Rather than as a conduit to heaven, he believed that Whites used Christianity as an accomplice to oppression. Malcolm argued: "Christianity is the white man's religion. The Holy Bible in the white man's hands and his interpretation of it have been the greatest single ideological weapon for enslaving millions of nonwhite human beings. Every country the white man has conquered with his guns, he has always paved the way, and salved his conscience, by carrying the Bible and interpreting it to call the people 'heathens' and 'pagans'; then he sends his guns, then his missionaries behind the guns to mop up" (Malcolm X [1965] 1973, 277).

To Malcolm, history had revealed Christianity's dehumanization of black people. He argued that, beginning with slavery, whites used Christianity to encourage black passivity: "This white man's Christian religion further deceived and brainwashed this Negro to always turn the other cheek, and grin, and scrape, and bow, and be humble, and to sing, and to pray and to take whatever was dished out by the devilish white man" (Malcolm X [1965] 1973). Malcolm X elevated black consciousness while simultaneously criticizing American racism. Malcolm (provided) (do you mean: insightful criticism) Malcolm insightfully criticized America's systemic racial practices and policies. Few understood the complexity and depth of racism in America, especially in the North, like Malcolm (Cone 1999c, xix). In addition, his black nationalism sparked a black revolution during the sixties, comprehensively impacting black life. Consequently, Malcolm and black nationalism contributed the essence of black identity to Cone's theology. "Malcolm taught me how to make theology black and never again despise my African origin" (Cone 1999b, 251). 


\section{Malcolm X: a Source for Cone's Theology}

Malcolm X challenged African Americans to accept and appreciate their blackness: culturally and historically, promoting a philosophy of black nationalism. Malcolm was "the most persuasive interpreter of black nationalism during the 1960s" (Cone 1999a, 103). Concurrently, he denounced American racism and the injuries Christianity had historically inflicted upon Black people. Hence, Malcolm contributed a black nationalistic ideology to Cone's theology. "When I turned to Malcolm X, I discovered my blackness and realized that I could never be who I was called to be until I embraced my African heritage - completely and enthusiastically" (Cone 1999c, xx). Malcolm's emphasis on blackness transformed Cone's ideological orientation and his nationalistic influence shaped the black identity of Cone's theology, allowing him to construct a theology suited exclusively to African Americans. According to Sales, "as a precondition for developing an effective movement for black liberation, Malcolm X insisted that Black people rethink their entire experience in the United States. Therefore, his most important contribution was an ideological one" (Sales 1994, 53). "Malcolm gave black theology its black identity, putting blackness at the center of who we were created to be" (Cone 1999c, xxi).

Cone further substantiates Malcolm's influence upon his theology: "I first heard Malcolm speak while I was a student at Garrett Theological Seminary in Evanston, IL, but I did not really listen to him. I was committed to Martin King and even hoped that he would accept the invitation offered him to become a professor of theology at Garrett. I regarded Malcolm as a racist and would have nothing to do with him" (Cone 1999c, xix). He continues:

Since I was, like many African-American ministers, a devout follower of Martin King, I tried initially to ignore Malcolm's cogent cultural critique of the Christianity as it was taught and practiced in black and white churches. I did not want him to disturb the theological certainties that I had learned in graduate school. But with the urban unrest in the cities and the rise of Black Power during the James Meredith March in Mississippi (June 1966), I could no longer ignore Malcolm's devastating criticism of Christianity, particularly as they were being expressed in the articulate and passionate voices of Stokely Carmichael, Ron Karenga, the Black Panthers, and other young African-American activists (Cone 1997a, viii).

However, Malcolm's influence swayed Cone away from King's philosophy of nonviolence and integration, as well as offering a stark alternative to the white expression of theology he had learned in seminary. Neither King's strategy nor traditional seminary teachings included black nationalism as a central theological component. Therefore, Malcolm was significant because he caused Black Christians to reevaluate their religion's ability to address black suffering.

Malcolm X's influence convinced Cone to develop black theology as "the religious counterpart of the more secular movement called 'black power.' This means that black theology is a religious explication of black people's need to define the scope and meaning of black existence in a white racist society" (Cone 1999b, 1084). Additionally he adds, it was clear to me that what was needed was a fresh start in theology, a new way of doing it that would arise out of the black struggle for justice and in no way 
would be dependent upon be [sic] approval of white academics in religion" (Cone 1990, xiii). Cone recalls: "Malcolm put the word black in black theology. He taught black scholars in religion and many preachers that a 'colorless Christianity' is a joke. As I listened to Malcolm and meditated on his analysis of racism in America and the world, I became convinced by his rhetorical virtuosity" (Cone 1991, 192). Therefore, Malcolm X's black consciousness and Black Power contributed to Cone's theology in three areas: black consciousness, rejection of white Christianity, and a black revolutionary theology.

\section{Black Consciousness}

Cone's encounter with Malcolm's black nationalism led him to integrate black consciousness into the schema of Christianity. Cone says, "it was the challenging and angry voice of Malcolm X that shook me out of my theological complacency. 'Christianity is the white man's religion,' he proclaimed, again and again, as he urged African-Americans to adopt a perspective on God that was derived from their own cultural history" (Cone [1969] 1997a, viii.). Therefore, Cone developed black theology as the religion of Black Power. It was designed to communicate the same nationalistic fervor as the secular Black Power movement, but from a Christian foundation. Together, Christianity and Black Power merged to formulate black theology. Cone argued:

Malcolm X taught black ministers and scholars that the identity of AfricanAmericans as a people was inextricably linked with blackness. This was his great contribution to black theology. Malcolm gave black theology its black identity, putting blackness at the center of who we were created to be. Malcolm did not write a scholarly treatise on the theme of blackness and self. He revolutionized black self-understanding with the power of his speech (Cone 1999c, xxi).

The more I read his writings and listened to his cogent and passionate oratory, the more I understood his message and was persuaded by it. As much as I am persuaded by the truth of the gospel of Jesus, I am equally persuaded that living and preaching Jesus' gospel in America require the exacting test of Malcolm's nationalist critique (Cone 1991, 152).

Malcolm identified the struggle as a black struggle. As long as black freedom and the Christian way in race relations were identified exclusively with integration and nonviolence, black theology was not possible. Integration and nonviolence required blacks to turn the other cheek to white brutality, join the mainstream of American society, and do theology without anger and without reference to the history and culture of African Americans. It meant seeing Christianity exclusively through the eyes of its white interpreters. Malcolm prevented that from happening (Cone 1996, 190).

Cone's quotations verify Malcolm's afrocentric contribution to his theology. Clearly, Malcolm played a key role in moving Cone's theology from one that encompassed white values to one with black consciousness at its core. Black consciousness was the 
mood of the sixties wherein Black people became aware of the "meaning of their blackness in the context of whiteness" (Cone 1970b, 244). Slogans such as "black pride," "black beauty," and "black power" emanated from his black nationalism.

Through a religious framework and black nationalistic methodology, Cone began to argue that "Black consciousness is the key to the black's man's emancipation from his distorted self-image" (Cone [1969] 1997b, 19). He further explicates: "Malcolm teaches us that African-Americans cannot be free without accepting their blackness, without loving Africa as the place of our origin and meaning" (Cone 1999b, 256). He writes of that era: "when black theologians began to concentrate on black culture and history, we realized that our own historical and cultural traditions are far more important for an analysis of the gospel in the struggle of freedom than are the western traditions which participated in our enslavement. We know that the people responsible for or indifferent to the oppression of blacks are not likely to provide the theological resources for our liberation" (Cone 1990, 18). Moreover, black consciousness linked Black theologians to a systematic analysis and approach to black suffering that was unlike anything white Christianity had provided.

Like Malcolm, Cone prioritized blackness as the existential lens through which he developed his theology. In the same manner that Malcolm declared, "I'm black first. My sympathies are black, my allegiance is black, my whole objectives are black," Cone said: "the order is significant. I am black first - and everything else comes after that" (Cone [1970] 1997a, 31). He repeatedly stressed this emphasis, explaining that "This means that I read the Bible through the lens of a black tradition of struggle not as the objective Word of God" (Cone [1975] 1997c, xi). Cone explicitly and incessantly agreed with Malcolm, even quoting him that black suffering resulted exclusively from black identity. Cone has said that "Malcolm's message is still true today. The crucial point is that we are black, and that fact alone ought to keep us open to each other"(Cone [1975] 1997c, 198).

Adopting Malcolm's black consciousness, Cone developed his theology integrating the culture and history of the black oppressed. He said: "under Malcolm X, theology cannot achieve its Christian identity apart from a systematic and critical reflection upon the history and culture of the victims of oppression" (Cone 1990, 17-18). Like Malcolm, Cone argued that self-hatred occurred when history and historical context were ignored. Malcolm recognized and expounded this truth far more clearly than anyone else in our history. That is why he was so severely criticized during his lifetime and seldom remembered today. Cone came to believe that black theology must begin with the black experience, the context of decision, action, and life. "How then does a

\footnotetext{
7 "Malcolm's most far-reaching impact was among the masses of African-Americans in the ghettos of the cities. He told them, as Baldwin observed, that 'they should be proud of being black and God knows they should be. This is very important thing to hear in a country that assures you that you should be ashamed of it"” However, "hearing Malcolm analyze the dreadful psychological consequences of black self-hatred had a transforming effect upon the consciousness of African-Americans. They began to think black and act black, because Malcolm, through the power of his oratory, helped them to realize and to accept their blackness as the essential element in the definition of their humanity. 'All of us are black first,' he told African-Americans, 'and everything else second." Cone continued: "Applying this talent, he decolonized the black mind, and thereby transformed 'Negroes' into proud black African people. Muhammad Ali proclaimed 'I am the greatest,' Aretha Franklin started to demand 'Respect,' James Brown began to sing 'I'm Black and I'm Proud,' and African-Americans began to say proudly to themselves and to the world that 'Black is beautiful, baby" (Cone 1991, 290-91).
} 
black Christian preacher and theologian like me understand and communicate the religious message of the Black Muslim minister like Malcolm?" (Cone 1984, 203). The most important thing that we have in common was also the source of his faith: the experience of being black in a white, racist society. He clearly articulates black experience as a source for his theology:

There is no truth for and about black people that does not emerge out of the context of their experience. Truth in this sense is black truth, a truth disclosed in the history and culture of black people. This means that there can be no Black Theology which does not take the black experience as a source for its starting point. Black Theology is a theology of and for black people, an examination of their stories, tales, and sayings. It is an investigation of the mind into the raw materials of our pilgrimage, telling the story of 'how we got over.' For theology to be black, it must reflect upon what it means to be black. Black theology must uncover the structures and forms of the black experience, because the categories of interpretation must arise out of the thought forms of the black experience itself (Cone 1991, 16-17; 1997a, b, c, 16-17).

Our common blackness and resistance to racism always empowered me to listen to him, over, and over again, until I found myself deeply engaged by his message" (Cone 1991, 152).

Black theology was therefore intrinsically bound to black history. Black history referred to the way blacks were brought to this land and the way they have been treated in American culture. It is the understanding of their history that describes their journey for freedom and defines their identity. Cone has argued that "If black theology is going to speak to the conditions of black persons, it cannot ignore the history of white inhumanity committed against them" (Cone [1970] 1990, 26). Naturally, black theology came also to encompass black culture. In Cone's definition, "Black culture consists of the creative forms of expression as one reflects on history, endures pain, and experiences joy. It is the black community expressing itself in music, poetry, prose and other art forms. Black theology must take seriously the cultural expressions of the community it represents so that it will be able to speak relevantly to the black condition" (Cone [1970] 1990, 26). Thus, Cone's use of black life in the development of black theology derived from Malcolm's rhetoric and linked black theology to black suffering and made it "able to speak relevantly to the black condition" (Cone 1972, 3).

\section{Rejection of Euro-American Christianity}

Although trained in white seminary, Cone realized Euro-American Christianity's inability to address black suffering. Thus, he learned from Malcolm that white Christianity destructively contributed to systemic racism that created oppression. Cone said of Malcolm: "No one before or after him analyzed the role of Christianity in promoting racism and its mental and material consequences upon lives of blacks as Malcolm did. He has no peer" (Cone 1996, 192). Cone acknowledges that "to understand white racism and black rage in America, I turned to Malcolm X and Black Power. Malcolm saw more clearly than King the depth and complexity of racism in America, especially in the North. The North was more clever than the South and thus knew how to camouflage its exploitation of black people" (Cone 1999c, xix). Malcolm incessantly 
criticized Euro-American Christianity, providing a critical model for Cone's theological development. According to Cone, "More than anyone else in America or European history (including Marx, Nietzsche, and Freud), Malcolm was the great 'master of suspicion' regarding white people's moral and religious values. All Americans, particularly White and Black Christians, should incorporate Malcolm's race critique into their understanding of their society and churches" (Cone 1991, 296).

Malcolm stridently and insightfully asserted that Christianity was the "white man's religion," created to enslave Black people and affirm white values. Cone understood and connected with Malcolm's belief that racism produces black self-hatred, inflicting psychological damage to Black people. Consequently, Cone incorporated this truth into his theology. He declared: "The greatest problem that all oppressed groups have is selfhatred. There is no way that whites could hold us in bondage so long, with minimal effective resistance and almost no coalition among us, without an effective use of negative and self destructive programming with each group. Malcolm X told AfricanAmericans unceasingly, the worst crime the white man has committed has been to teach us to hate ourselves" (Cone 1984, 159).

Malcolm's suspicion of white religion led Cone to the conclusion that black theology must deviate from the theology of the white community. He argued: "since it seeks to interpret Black Power religiously, Black Theology endeavors to re-order the Christian tradition in view of the black predicament and to destroy the influence of heretical white Christianity" (Cone [1969] 1997a, 13). Cone insisted that Malcolm was not completely wrong by calling the "white man the devil," because "the white structure of this American society, personified in every racist, must be at least part of what the New Testament meant by the demonic forces" (Cone [1969] 1997a, 40-41). Therefore, Cone chastised American theology for failing to relate "its work to the oppressed in society by refusing to confront the structures of this nation with the evils of racism," suggesting that "There is really one answer: American theology is racist; it identifies theology as dispassionate analysis of the 'tradition,' unrelated to the sufferings of the oppressed" (Cone [1970] 1990, 18).

Mirroring Malcolm's rhetoric, Cone writes that: "during slavery the social limitation of white theology was expressed in three main forms: (1) some white theologians ignored slavery as a theological issue; (2) others justified it; and (3) only a few spoke out against it" (Cone [1975] 1997c, 43). Therefore, he said, "black theologians could not remain silent about the ever increasing manifestations of racism in the white church and theology. We had to speak out or there would be no way we could defend ourselves from the 'white religion' but also attack it and thus uncover its demonic and sinister nature" (Cone 1984, 40). Cone embraced and further advanced Malcolm's warning to be aware of white Christianity's impact upon the black community. It would be difficult to create a black Christian faith without rejecting damaging impact of white Christianity. Thus, having been trained in the European construct of Christianity, Cone was convinced that white theologians were unable and unwilling to address black people's struggles for racial justice. He argued: "most white theologians who attend learned societies and write books and articles on theology fall in the first group. These theologians believe in rigorous scholarship and disciplined scientific thinking, but this process invariably fails to grapple with the problem of color. They conveniently play down the fact that their very definition of theology is culturally bound and thus belies their claims about universality" (Cone [1975] 1997c, 46). 
Malcolm rejected Christianity completely and embraced the Nation of Islam as the religion for black people. ${ }^{8}$ In contrast, Cone developed black theology as the religion for Black people, with its basis in Christianity. Cone, unwilling to abandon, relinquish, or convert to the Nation of Islam, instead, developed black theology as an afrocentric religious alternative to the Black Muslims. Recognizing that white theologians were unwilling to address the issue of color, Cone constructed his Christian theology using themes from Malcolm X, such as "the importance of social location, context, and the hermeneutic of suspicion. He also anticipated the liberation emphasis on social analysis and the unmasking of hidden assumptions" (Burrow 1994, 15). In his black theology, Cone argued that Black people must relinquish dependence upon White Americans for support, affirmation, or validation. "The same critique that Malcolm X made regarding the white support of Martin King and other integrationist participants in the civil rights movement is applicable here. Any movement of freedom that is dependent upon the oppressor's support for survival is doomed to failure from the start" (Cone 1984, 91).

\section{Revolutionary Theology}

Cone declared and advanced the ideology that black theology imperatively "seeks to be revolutionary in the sense that it attempts to bring to theology a special attitude permeated with black consciousness" (Cone [1969] 1997a, 32). The revolutionary language of Cone's theology developed from Malcolm's black revolutionary philosophy. Malcolm's black militancy promoted a revolutionary method that included selfdefense. In Malcolm's model this self-defense could include violence, arguing than it was justifiable to defend oneself, wife, and children. In a speech delivered on November 10, 1963, in Detroit, "Message to the Grass Roots," Malcolm said "you don't have a peaceful revolution. There's no such thing as a nonviolent revolution. A revolution is bloody. Revolution is hostile. Revolution knows no compromise. Revolution overturns and destroys everything that gets in its way" (Malcolm X 1965a, 7).

Accordingly, Cone's revolutionary theology developed from and of critical necessity responded to a central question: "How is Christianity related to the black revolution in America?" This question originated from an American context that could only see a "discontinuity between 'blackness-revolution"” and the gospel of Jesus (Cone 1975, 5). Cone recognized that most would not easily recognize a connection between revolution and the gospel, lamenting the fact that "Christians, unfortunately, are not known for their revolutionary actions" (Cone 1975, 7). However, Cone passionately argued that the gospel is indeed revolutionary. It radically and aggressively confronts evils systems and challenges Christians to social action: "It would seem that it is time for theology to make a radical break with its identity with the world by seeking to bring to the problem

\footnotetext{
${ }^{8}$ The Nation of Islam claimed that they were the religion for black people. The teachings proclaim that the black man is the original man, ancestor to the entire human race. Following in the teachings of Elijah Muhammad and the Nation of Islam, Malcolm equated Christianity with slavery, segregation, racism, suffering and death of black people. Malcolm was convinced that black people should reject Christianity and embrace Islam which represented, for them, peace, justice freedom, equality, and human dignity. For Malcolm, Christianity is white nationalism; Islam is black nationalism. Christianity enslaves blacks; Islam liberates them. Christianity divides blacks; Islam unites them. Christianity teaches that black is a curse and Islam teaches that it is a blessing to be black. According to Cone, "These two ideas - the utter rejection of white values and the embracing of black history and culture-lay at the heart of Elijah Muhammad's teachings, and they became the center of Malcolm's philosophy" (Cone 1991, 52).
} 
of color the revolutionary implications of the gospel of Christ. It is time for theology to leave its ivory tower and join the real issues, which deal with the dehumanization of blacks in America" (Cone [1969] 1997a, 83).

For Cone, the gospel revolutionizes theology. It rejects passivity and directly confronts white society as the racist Antichrist, communicating to the oppressor that nothing will be spared in the fight for freedom (Cone [1969] 1997a, 135). He defined revolutionary theology as "a sudden, radical and complete change" from the theology of the white oppressors in order to unite with the black-oriented movement established by black revolutionaries (Cone [1969] 1997a, 2). Cone writes: "the liberation theme relates black power to the Christian gospel, and renders as untruth the unverbalized white assumptions that Christ is white, or that being Christian means that black people ought to turn the other cheek - as if we blacks have no moral right to defend ourselves from the encroachments of white people" (Cone 1975, 8). Black theology believes the problem of racism will not be alleviated through talk but action. For Black people revolution means that Blacks no longer accept the history of White America as central to their existence, and they are determined to insure their present and future existence will be defined by black visions of reality.

Realizing that white racism is an insanity comparable to Nazism, black theology seeks to articulate a theological ethos consistent with the black revolutionary struggle. Blacks know that there is only one possible authentic existence in this society, and that is to force a radical revolutionary confrontation with the structures of white power saying yes to the essence of their blackness. The role of black theology is to tell blacks to focus on their own self-determination as a community by preparing to do anything the community believes necessary for its existence (Cone [1970] 1990, 15).

Further, in the spirit of Malcolm, Cone argues that American society could no longer restrict, limit, or hinder their social progress. Instead, black revolutionary theology insists that Black people must chart their own vision and methods for socio-political advancement.

Cone's black revolutionary theology rejected the pacification of any black movement that accepted a gradual integration into the white community - and it was this orientation that irrefutably reflected Malcolm's influence. He disregarded "token handouts" to appease Black people's requests for racial justice and social equality. Black revolutionary theology rejected a "subterfuge for white supremacy; i.e., as always involving only a token number of Negroes integrated into white institutions on the white man's terms" (Cone [1969] 1997a, 18. . Cone questioned integration as an adequate goal for African Americans. He came to believe that Black people should only pursue integration with certain stipulations. This stance in black theology mirrors Malcolm. For example, during an interview, Malcolm ordered a cup of coffee and asked for cream. He looked at the interviewer, smiled, and said, "my coffee is the only

\footnotetext{
${ }^{9}$ Malcolm X rejected integration in the revolutionary process. He said: "Revolution is never based on begging somebody for an integrated cup of coffee. Revolutions are never based upon negotiations. Revolutions are never based upon any kind of tokenism whatsoever. Revolutions are never based upon that which is begging a corrupt society or a corrupt system to accept us into it. Revolution overturns systems. And there is no system on this earth which has proven itself more corrupt, more criminal, than this system that in 1964 still colonizes 22 million African-Americans, still enslaves 22 million Afro-Americans” (Malcolm X 1965b, 50).
} 
thing that I want integrated." Cone maintained that integration could only occur if each group met on equal grounds, with neither privileging its values over the other's.

If integration could not be accomplished on mutually acceptable grounds, radical protest - even separation - was necessary. Cone declared that black revolutionary theology pursued the "complete emancipation of black people from white oppression by whatever means black people deem necessary" (Cone [1969] 1997a, 6). In this sense, Cone's black revolutionary language was identical to Malcolm's, who said: "We declare our right on this earth to be a human being, to be respected as a human being, to be given the rights of a human being in this society, on this earth, in this day, which we intend to bring into existence by any means necessary. Cone further specified the methods he advocated: "the methods may include selective buying, boycotting, marching, or even rebellion. Black Power means freedom, self-determination, wherein black people no longer view themselves as without human dignity but as men, human beings with the ability to carve out their own destiny" (Cone [1969] 1997a, 6).

Black revolutionary theology demanded that White people respect Black people as equals. During that period, Cone said: "what is needed, then, is not 'integration' but a sense of worth in being black, and only black people can teach that. Black consciousness is the key to black man's emancipation from his distorted self-image" (Cone [1969] 1997a). Black revolutionary theology demanded that Black people be treated with equality and respect, and Cone was impatient and unwilling for the White American to determine when this would occur.

Cone demanded that his theology preserved Black people's indelible rights to life, liberty, and the pursuit of happiness. Consequently, his revolutionary black theology also reserved the right for self-defense, if necessary. He explained his intention thus: "self-defense is defense of oneself when physically attacked. Black victims of racially motivated violence have the right, morally and legally, to protect themselves against the brutality of white hate groups who assume that merely because they are white they have the right to violate black humanity" (Cone 1999a, 70). Cone believed that no one had expressed Black people's right to defend themselves more convincingly than Malcolm $\mathrm{X}$ : "self-defense is nothing but the defense of one's right to exist with dignity. No one expressed this point for the black community more forcefully than Malcolm X: 'Respect me, or put me to death. But when you start to put me to death, we're both going to die together"' (Cone 1999a).

Cone acknowledged Malcolm's influence upon his perspective of violence and vengeance:

As can be clearly seen in what I have already said, my perspective on violence and vengeance has been strongly influenced by the life and thought of Malcolm $\mathrm{X}$. His influence makes black identity and self-defense important in my analysis. He forces me to think from the vantage point of the victims, refusing to accept the logic of oppressors as the appropriate way to think about justice, peace, and violence. . . . Although whites portrayed Malcolm as a champion of hatred and violence, nothing could have been further from his intentions. He merely liberated the minds of many blacks, destroying their self-hate by advocating respect for and love of blackness. When blacks heard Malcolm, many were empowered for the first time to stand up like human beings and claim their dignity. 
It was Malcolm's challenge to the Christian Church that motivated me to think deeper about the relationship between the black experience and the Christian faith. His logic was so persuasive: 'I believe in a religion that believes in freedom. Any time I have to accept a religion that won't let me fight a battle for my people, I say to hell with that religion.' Does Christianity believe in freedom and will it let me fight for it? Wrestling with that question forced me to become a theologian of black liberation. It was clear to me then and now that if the answer had been negative, I could not be a Christian (Cone 1999a, 71).

Malcolm had revealed the fact that violence had become ingrained in the fabric of American society, that it was a way of life: "America was born in violence, defended her rights through violence, and even protected her racist laws through violence (Malcolm 1965a, 48). In dialog with this philosophy, Cone argued that since a nation has the right to defend its national interests with violence, than Black people should also exercise their rights to protect their human interests.

Malcolm regularly indicted America for justifying violence when it protected her interests, but condemning Black people for using it to protect their own interests. Cone has said that Malcolm's indictment enlightened him about the reality that "all too often violence is exclusively identified with the oppressed and seldom with the Oppressors" (Stewart 1989, 189). Cone states:

The radical rejection of hatred and vengeance does not mean that we accept white people's analysis of violence and nonviolence. We are well aware that they derive their analysis of these terms from a theological and political interest that supports the status quo, whereas we must analyze them in accordance with our struggle to be free. We cannot let white rhetoric about nonviolence and Jesus distort our vision of violence committed against black people. Therefore, one of the tasks of the black ethicist is to untangle the confused and much discussed problem of violence and nonviolence and Jesus' relationship to both. (1) Violence is not only what black people do to white people as victims seek to change the structure of their existence; it is also what white people did when they created a society for white people only, and what they do in order to maintain it. (2) If violence is not just a question for the oppressed but primarily for the oppressors, then it is obvious that the distinction between violence and nonviolence is an illusory problem (Cone [1975] 1997c, 199-202).

Cone, drawing from Malcolm's influence, argued that White America articulated a definition of violence and self-defense that justified and perpetuated their privileged status. They created an American ethos conducive to violence by enacting segregation laws and brutalizing those who resisted the laws in the pursuit of justice. To mitigate violence, Cone argued, Whites encouraged Blacks to patiently and subserviently wait on the inevitability of desegregation, encouraging at minimum nonviolent peaceful demonstrations which best represent Christian virtues. However, Cone argued, "again I thought of Malcolm: 'Don't let anybody who is oppressing us ever lay the ground rules. Don't go by their games, don't play the game by their rules. Let them know now that this is a new game, and we've got some new rules."' (Cone [1970] 1990, xiii). 


\section{Conclusion}

Malcolm elevated black consciousness, encouraging black people to appreciate their cultural and historical blackness. At the same time, Malcolm was the foremost critic of American racism and one of White Christianity's staunchest opponents. West described Malcolm as "the prophet of black rage primarily because of his great love for black people. His love was neither abstract nor ephemeral. Rather, it was a concrete connection with a degraded and devalued people in need of psychic conversion" (West 1993, 136).

The Black Power movement created a theological and sociopolitical dilemma for Black theologians and pastors. Attempting to reconcile the problem of what it meant to be a Black Christian in a white racist society and seeking to address the disenfranchisement of African Americans, they had to contend with the concerns raised by Black Power advocates. ${ }^{10}$ Black power supporters embraced a more radical approach to social transformation than King and the Christian-based civil rights movement. ${ }^{11}$ Black Christians had to decide whether they would dismiss the Black Power platform as mere inflammatory rhetoric, or whether they could reconcile Black Power arguments with their faith.

Regardless, it was obvious that black clergy could no longer ignore the momentum established by the black power movement and its impact on black Christians. The Black church was thus faced with a theological dilemma: either reject Black Power as a contradiction of Christian love (and thereby join the white church in its condemnation of Black Power advocates as un-American and unchristian), or accept Black Power as a sociopolitical expression of the truth of the gospel. This was their dilemma. How could they reconcile Christianity and Black Power, Martin King and Malcolm X?

Cone did not resolve the tension between Christianity and Black Power by choosing one over the other. Instead, he resolved the dilemma by integrating King's protest theology with Malcolm's black consciousness. His love for Black people motivated him to incorporate Malcolm's Black Nationalism into his Christian theology. As Gary Dorrien has noted, "the echoes of Malcolm X thus resounded throughout Cone's early and subsequent writings. Though he later revised several key aspects of his theology in response to criticisms from black theologians, Cone's commitment to Malcolm X-like Black Power perspective has remained central to his work" (Dorrien 1995, 235). Cone was able to fuse Malcolm's black nationalism with the Christian faith, giving birth to a theology relevant to black suffering.

\footnotetext{
${ }^{10}$ Stokely Carmichael, who later changed his name to Kwame Ture, and Charles Hamilton argued that "the adoption of the concept of Black Power is one of the most legitimate and healthy developments in American politics and race relations in our time. Black Power is a call for black people in this country to unite, to recognize their heritage, to build a sense of community. It is a call for black people to begin to define their own goals, to lead their own organizations and to support those organizations. It is a call to reject the racist institutions and values of this society" (Ture and Hamilton 1992, 44).

11 "When Carmichael and other radical black activists separated themselves from King's absolute commitment to nonviolence by proclaiming black power, white Christians, especially members of the clergy, called upon their black brothers and sisters in the gospel to denounce black power as un-Christian" (Cone 1984, 10)."Black power advocates made no claim to an identity derived from Christianity. Most were secular university students or adherents of African religions, and all tended to define Christianity as the 'white man's religion.' Black preachers, in their struggle to be Christian and support black power had to develop a theology that was distinctly black and also accountable to our faith" (Cone 1984, 59).
} 
Open Access This article is licensed under a Creative Commons Attribution 4.0 International License, which permits use, sharing, adaptation, distribution and reproduction in any medium or format, as long as you give appropriate credit to the original author(s) and the source, provide a link to the Creative Commons licence, and indicate if changes were made. The images or other third party material in this article are included in the article's Creative Commons licence, unless indicated otherwise in a credit line to the material. If material is not included in the article's Creative Commons licence and your intended use is not permitted by statutory regulation or exceeds the permitted use, you will need to obtain permission directly from the copyright holder. To view a copy of this licence, visit http://creativecommons.org/licenses/by/4.0/.

\section{References}

Bassey, M. O. (1999). Malcolm X: Islam and African American self-consciousness. Dialogue and Alliance Spring-Summer: 50-65.

Breitman, G. (1967). The last year of Malcolm X: the evolution of a revolutionary. New York: Pathfinder Press.

Burrow, R. (1994). James H. Cone and black liberation theology. Jefferson, NC: McFarland.

Cone, J. H. (1970a). Black theology and black liberation. Christian Century, 87, 1084-1088.

Cone, J. H. (1970b). Black consciousness and the black church: a historical-theological interpretation. Christianity and Crisis, 30, 244-250.

Cone, J. H. (1972). The spiritual and the blues. New York: Seabury Press.

Cone, J. H. (1975). Black theology on revolution, violence, and reconciliation. Union Seminary Quarterly Review, 31, 5-14.

Cone, J. H. (1984). For my people: black theology and the black church. Maryknoll: Orbis Books.

Cone, J. H. (1986). My soul looks back. Maryknoll: Orbis Books.

Cone, J. H. (1990). Black theology from a historical perspective. Bangalore Theological Forum, 22, 1-25.

Cone, J. H. (1991). Martin and Malcolm and America: a dream or a nightmare. Maryknoll: Orbis Books.

Cone, J. H. (1992). Malcolm X: the impact of a cultural revolutionary. Christian Century, 109(1189-91), 93-95.

Cone, J. H. (1996). "Martin, Malcolm, and black theology." Pp 185-195 in Future of theology: essays in honor of Jürgen Moltmann, edited by M. Volf, C. Krieg, and T. Kucharz. Grand Rapids: Eerdmans.

Cone, J. H. [1969] (1997a). Black theology and black power. Reprint, Maryknoll: Orbis Books.

Cone, J. H. [1970] (1997b). A black theology of liberation. 20th anniversary ed. Reprint, Maryknoll: Orbis Books.

Cone, J. H. [1975] (1997c) God of the oppressed. Reprint, Maryknoll: Orbis Books.

Cone, J. H. [1986] (1999a). Speaking the truth: ecumenism, liberation, and black theology. Reprint, Maryknoll: Orbis Books.

Cone, J. H. (1999b). Looking back, going forward: black theology as public theology. In D. Hopkins (Ed.), Black faith and public talk (pp. 246-259). Maryknoll: Orbis Books.

Cone, J. H. (1999c). Risks of faith: the emergence of black theology of liberation, 1968-1998. Boston: Beacon Press.

Cone, J. H. (2004). The vocation of a theologian. In L. E. (Ed.), Living stones in the household of God: the legacy and future of black theology (pp. 203-212). Philadelphia: Fortress Press.

Dorrien, G. (1995). Soul in society: The making and renewal of social Christianity. Minneapolis: Fortress Press.

Dyson, M. (1995). Making Malcolm: the myth and meaning of Malcolm X. Oxford: Oxford University Press.

Gallen, D. (1992). Malcolm X as they knew him. New York: Carrol \& Graf Publishers.

Goldman, P. (1979). The Death and Life of Malcolm X. Champaign: University of IL.

Hopkins, D. (1993). Shoes that fit our feet: sources for a constructive black theology. Maryknoll: Orbis Books.

Hopkins, D. (2002). Heart and head: black theology: past, present and future. New York: St. Martin's Press.

Karim, I. B. (1971). The end of white world supremacy: four speeches by Malcolm X. New York: Arcade Publishing.

Malcolm, X. (1962). Black man's history. In I. Karim (Ed.), The end of white world supremacy: four speeches by Malcolm X. New York: Arcade Publishing

Malcolm, X. (1965a). Message to the grass roots. In G. Breitman (Ed.), Malcolm X speaks. New York: Grove Press.

Malcolm, X. (1965b). The black revolution. In G. Breitman (Ed.), Malcolm X speaks. New York: Grove Press.

Malcolm, X. (1973). The autobiography of Malcolm X, with the assistance of Alex Haley. New York: Ballantine Books.

Sales, W. (1994). From civil rights to black liberation: Malcolm X and the organization of Afro-American unity. Boston: South End Press. 
Stewart, C. (1989). God, being and liberation: a comparative analysis of the theologies and ethics of James H. Cone and Howard Thurman. Lanham: University Press of America.

Ture, K. and Hamilton, C. V. [1967] (1992) Black power: the politics of liberation. Reprint, New York: Vintage Books. West, C. (1993). Race matters. New York: Vintage Books.

Publisher's Note Springer Nature remains neutral with regard to jurisdictional claims in published maps and institutional affiliations. 